\title{
Sovjetska diplomacija o nastanku Nezavisne Države Hrvatske
}

\author{
ALEKSANDAR ŽIVOTIĆ \\ Filozofski fakultet u Beogradu \\ Beograd, Srbija \\ aleksandar.zivotic@f.bg.ac.rs
}

\begin{abstract}
U radu se na temelju do sada nepoznatih i nekorištenih dokumentarnih izvora sovjetskoga podrijetla predstavljaju i analiziraju stavovi sovjetske diplomacije prema uzrocima nastanka i okolnostima u kojima se formirala Nezavisna Država Hrvatska. U tekstu je prikazan sovjetski odnos prema samom činu njezina proglašenja, posljedicama koje je njezin nastanak imao na sudbinu jugoslavenske kraljevine i ulozi Italije i Njemačke u formiranju i prvim danima postojanja Nezavisne Države Hrvatske. Rad sadržava i pregled stavova Sovjetskoga Saveza prema hrvatskom pitanju u jugoslavenskoj državi međuratnoga perioda i sovjetskih diplomatskih ocjena međunarodnih razmjera hrvatskoga problema u međuraću i prvim danima Drugoga svjetskog rata.
\end{abstract}

Ključne riječi: Sovjetski Savez; Nezavisna Država Hrvatska; diplomacija; Njemačka; Italija; 1941.; Travanjski rat

Jugoslavenska kraljevina i sovjetska Rusija, a potom Sovjetski Savez nisu imali redovne diplomatske odnose sve do ljeta 1940. godine. Niz političkih i ideoloških okolnosti utjecao je na jugoslavensku državu i njezina monarha kralja Aleksandra da prema „prvoj zemlji socijalizma” zauzme izričito negativan stav. Strah od širenja revolucije, utjecaj brojne ruske emigracije koja je nakon sloma „bijelih” našla utočište na jugoslavenskom tlu, specifičan odnos sovjetskih vlasti prema nacionalnom pitanju u Jugoslaviji, kao i politika velikih sila - jugoslavenskih saveznica činili su da usprkos mnogobrojnim pokušajima koji su imali za cilj normalizaciju diplomatske komunikacije dvije države praktično do predvečerja Drugoga svjetskog rata na Balkanu nemaju uređene međusobne odnose. Početak Drugoga svjetskog rata na europskom tlu natjerao je jugoslavensku vladu da započne s politikom aktivnoga približavanja Sovjetskom Savezu, ali je karakter sovjetske intervencije u Poljskoj, a potom i započinjanje Sovjetsko-finskoga rata otežavalo započete razgovore. U proljeće 1940., nakon završetka sovjetsko-finskoga sukoba, stvorile su se mogućnosti 
za okončanje pregovora koji su rezultirali potpisivanjem trgovinskoga ugovora i uspostavljanjem diplomatskih odnosa. Našavši se u teškom vanjskopolitičkom položaju, suočena s mogućnošću talijanskoga, a potom i njemačkoga vojnog napada i lišena mogućnosti potpore Francuske kao dotadašnje glavne saveznice, jugoslavenska vlada pokušala je osigurati svoj strateški oslonac na Sovjetski Savez. Sa svoje strane vođa Hrvatske seljačke stranke Vladko Maček smatrao je da Jugoslavija s obzirom na svoje okruženje mora uspostaviti bliske kontakte sa Sovjetskim Savezom. Zajedno s predsjednikom vlade Dragišom Cvetkovićem i ministrom vanjskih poslova Aleksandrom Cincar-Markovićem tražio je od kneza Pavla da pristupi jačem diplomatskom i vojnom vezivanju za Sovjetski Savez da bi na taj način parirao agresivnoj talijanskoj politici na Balkanu. ${ }^{1}$ On je nastupio sa svojom starom tezom da sovjetski faktor na Balkanu u novonastalim uvjetima, obilježenim pojačanim pritiskom Njemačke i Italije, ali i proturječnošću njihovih interesa u regiji, ima ulogu uspostavljanja ravnoteže, što za jugoslavensku kraljevinu otvara mogućnost političkoga balansiranja i pogodnijega strateškog opredjeljenja i oslonca u slučaju potrebe. ${ }^{2}$ $\mathrm{Na}$ njihovo veliko iznenađenje, knez Pavle, koji je slovio za velikoga protivnika komunista, složio se s njihovom inicijativom. ${ }^{3}$ Maček se poslije hvalio da polovina zasluga za obnovu odnosa sa Sovjetskim Savezom pripada njemu. Ipak, nije krio svoje nepovjerenje u mogućnost sovjetske vojne pomoći Jugoslaviji. Shvaćajući buduću važnost sovjetskoga faktora na Balkanu, Maček je nastojao da preko svojega suradnika - trgovinskoga atašea u Moskvi Franje Gažija, koji je na tu dužnost poslan na njegovo inzistiranje - ima siguran kanal preko kojega će dobivati pouzdane informacije, i one vezane za unutrašnja zbivanja u Sovjetskom Savezu i one koje su se ticale sovjetske politike na Balkanu. ${ }^{4}$ Nasuprot Mačeku i Hrvatskoj seljačkoj stranci, hrvatski nacionalisti negativno su gledali na Sovjetski Savez, često izjednačavajući „Beograd i Moskvu”. Ipak, uslijed niza godina međusobne udaljenosti, ideoloških sumnji i predrasuda, kao i prioriteta sovjetske vanjske politike, koji su se odnosili na očuvanje kontura sporazuma s Njemačkom, to se nije dogodilo do sloma jugoslavenske kraljevine. Njezin poraz u Travanjskom ratu, a potom i okupacijska podjela njezina teritorija učinili su da sovjetska diplomacija u iščekivanju njemačkoga napada na Sovjetski Savez budno prati zbivanja na jugoslavenskom prostoru. ${ }^{6}$

Jedno od najvažnijih pitanja za sovjetsku diplomatsku službu odnosilo se na formiranje Nezavisne Države Hrvatske, njezin unutarnji karakter i mjesto i

\footnotetext{
1 O talijanskim interesima na Balkanu opširnije: NENEZIĆ, Jugoslovenske oblasti pod Italijom 1941-1943; BERGVIN, Imperija na Jadranu.

2 BOBAN, Maček i politika Hrvatske seljačke stranke 1928-1941, 322.

MAČEK, Memoari, 141.

JОВАНОВИЋ, Политичке успомене, 143-145.

JAREB, Ustaško-domobranski pokret, 474.

6 O jugoslavensko-sovjetskim odnosima opširnije: CVETKOVIĆ, „Jugoslovensko-sovjetski pregovori 1941”, 11-26; БЈЕЛАЈАЦ, „Покушај стратешког ослонца на СССР 1939-1941”, 4166; ЖИВОТИТ, Југословенско-совјетски односи 1939-1941; ВОЛКОВ, ГИБИАНСКИЙ, Восточная Европа между Гитлером и Сталиным.
} 
ulogu u budućim njemačkim i talijanskim projekcijama preoblikovanja jugoslavenskoga prostora. Dostupni sovjetski izvori o Nezavisnoj Državi Hrvatskoj koje ovom prilikom prezentiramo nastali su između sredine travnja i početka lipnja 1941., odnosno od trenutka pristizanja vijesti o proglašenju hrvatske države u Moskvu do momenata koji su prethodili njemačkom napadu na Sovjetski Savez. Radi se o specijaliziranim elaboratima i izvještajima nastalim u okviru IV. europskog odjeljenja Narodnoga komesarijata vanjskih poslova pod rukovodstvom uglednoga diplomata i znanstvenika Nikolaja Novikova ${ }^{7}$, koji su po svojoj namjeni i sadržaju bili za vodstvo sovjetske diplomacije te partijsko i državno rukovodstvo. Materijali nastali u okviru toga odjeljenja bili su zasnovani na izvještajima i telegramima sovjetskih diplomatskih i konzularnih predstavništava u europskim prijestolnicama, posebno država zainteresiranih za zbivanja na prostoru jugoslavenske kraljevine. Najpouzdaniji izvor informiranja sovjetske diplomacije o događajima tijekom Travanjskoga rata, a posebno nakon vojnoga poraza Kraljevine Jugoslavije, bilo je sovjetsko poslanstvo u Beogradu, odnosno otpravnik poslova Viktor Lebedev i vojni izaslanik general-major Aleksandar Samohin. Sovjetsko poslanstvo ostalo je u Beogradu do kraja svibnja 1941. te je, iako udaljeno od centra zbivanja, bilo u prilici intenzivno pratiti zbivanja u neposrednom okruženju, a Lebedev i Samohin nalazili su se tijekom kritičnih travanjskih dana 1941. na prostorima Bosne, Hercegovine i Hrvatske, pa su s lica mjesta svjedočili o prvim danima Nezavisne Države Hrvatske. Na drugoj strani, izvjestan broj građanskih političara i oficira naklonjenih Sovjetima, koji su i u predratnom periodu bili bliski sovjetskim predstavnicima u Jugoslaviji, često je slovio za siguran sovjetski izvor informacija o političkim i vojnim zbivanjima, a veze s komunistima održavane su linijom Kominterne i zbog svoje političke osjetljivosti nisu bile dio uobičajenoga diplomatskog informiranja.

Sovjetska diplomacija promatrala je nastanak jugoslavenske države i međunacionalne odnose u njoj na temelju postavki boljševičke ideologije. Smatralo se da temelj jugoslavenske države čine srpsko-hrvatski odnosi i da unutarnje međunacionalne probleme treba riješiti preuređenjem države na federalnoj osnovi, gdje bi Slovenija, Hrvatska, Dalmacija, Srbija, Crna Gora i Makedonija činile posebne jedinice na temelju načela slobodno izražene volje naroda i pune ravnopravnosti svih nacionalnosti. Na taj način sovjetska je vlada nastojala sanirati štetu koju je izazvala odluka Petoga kongresa Kominterne 1924., koja je govorila da Jugoslaviju kao umjetnu tvorevinu treba razbiti. Zato se sovjetska vlada posebnom deklaracijom o međunarodnim pitanjima čvrsto založila za

7 Nikolaj Vasiljevič Novikov (1903. - 1989.). Po završetku školovanja na Lenjingradskom istočnom institutu radio je u Ministarstvu vanjske trgovine SSSR-a i povremeno predavao ekonomiju Turske i bliskoistočnoga svijeta na Moskovskom institutu za istočne studije. Od 1938. u Narodnom komesarijatu za vanjske poslove SSSR-a konzultant Prvoga istočnog odjeljenja, a potom načelnik Bliskoistočnoga i Četvrtoga europskog odjeljenja. Od 1943. veleposlanik u Egiptu i istovremeno pri vladama u izbjeglištvu Grčke i Jugoslavije. Veleposlanik u Washingtonu (1946. - 1947.). Član Saveza pisaca SSSR-a od 1950. godine. 
unutarnji preobražaj jugoslavenske države na bazi federativnoga uređenja. ${ }^{8} \mathrm{Za}$ sovjetsku stranu jugoslavenska kraljevina bila je država u kojoj je hegemoniju imala „velikosrpska buržoazija” zahvaljujući potpori sila Antante na kraju Prvoga svjetskog rata. Što se tiče držanja „hrvatske buržoazije” u trenucima nastanka jugoslavenske kraljevine, a potom i prvih godina njezina postojanja, smatralo se da je ona uplašena „revolucionarnim pokretom u zemlji”, a kako nije raspolagala realnim snagama uz pomoć kojih bi mogla ugušiti taj pokret, iz krajnje oportunih razloga stvorila je kompromis sa srpskom buržoazijom, „koju je pozvala u pomoć da bi ugušila radničke mase Hrvatske”. Sa sovjetske strane isticalo se da je upravo uslijed takva pristupa ujedinjenju Hrvatska izgubila i „skromna autonomna prava” kojima je raspolagala u sastavu nekadašnje Austro-Ugarske. ${ }^{9} \mathrm{Na}$ drugoj strani, glavni uzrok nezadovoljstva najvećega dijela hrvatskoga naroda viđen je u „šovinističkoj velikosrpskoj politici beogradske vlade" jer samo ujedinjenje nije poboljšalo položaj hrvatskoga naroda. Sovjeti su smatrali da je Hrvatska seljačka stranka kao politička partija koja je aktivno djelovala na političkoj sceni od 1905. zastupala interese „vladajućih klasa” i da je, plašeći se gubitka utjecaja u hrvatskim masama, bila „prinuđena istupati protiv srpskoga pritiska” tražeći političku autonomiju za Hrvatsku i poboljšanje socijalnoga položaja seljaštva, što - po sovjetskim stavovima - nije smetalo njezinu vodstvu da se „često dogovara sa Srbima” i povremeno ulazi u sastav vlade. Shodno vladajućoj ideološkoj matrici, sovjetska diplomacija objašnjavala je postojeće srpsko-hrvatske nesuglasice ideologiziranim tumačenjem da su „klasne proturječnosti” dobile formu „međunacionalnih proturječnosti”, što se "poput crvene niti” provlačilo tijekom cijele međuratne Jugoslavije. ${ }^{10}$ Kao događaj koji je presudno utjecao na pogoršanje srpsko-hrvatskih odnosa Sovjeti su markirali skupštinski atentat u Beogradu 1928. godine. Po njima, tada je ,jedan srpski nacionalist sa skupštinske govornice” ubio vođu Hrvatske seljačke stranke Stjepana Radića te Đuru Basaričeka i Pavla Radića, nakon čega je vodeću ulogu unutar te stranke preuzeo Vladko Maček, koji je zastupao „radikalnije političke metode”. ${ }^{11}$

Usprkos krajnje negativnu stavu prema kralju Aleksandru, njegovu političku djelatnost nakon atentata u Skupštini sovjetska je diplomacija ocjenjivala dobrim dijelom pozitivno. Isticalo se da je kralj Aleksandar, iako je težio uvođenju potpune diktature u zemlji, bio prinuđen u siječnju 1929. suspendirati ustav i raspustiti sve postojeće političke stranke u cilju suprotstavljanja djelovanju postojećih separatističkih pokreta u zemlji. Time je objašnjavana i nova administrativna podjela zemlje, kojom su uništene stare historijske oblasti. $\mathrm{Na}$ taj je način prostor Hrvatske razdijeljen između četiri novoformirane banovine, što su Sovjeti smatrali jednim od glavnih razloga novoga vala hrvatskoga nezadovoljstva. Sovjeti su ocjenjivali da je na valu općega nezadovoljstva

\footnotetext{
8 RF-RGASPI, f. 17, o. 162, d. 2, 1. 2-5.

9 RF-AVPRF, 6, o.3, d. 373, p. 27, 1. 115.

10 RF-AVPRF, 6, o.3, d. 373, p. 27, 1. 115.

11 RF-AVPRF, 6, o.3, d. 373, p. 27, 1. 17.
} 
karakterom osobnoga režima kralja Aleksandra došlo i do jačanja prosvjeda hrvatskih političkih djelatnika, a posebno krajnjih nacionalista, koji su već bili poznati po svojim separatističkim težnjama. U tim ocjenama i analizama posebno se apostrofiralo da je takva politička situacija presudno utjecala na jačanje djelatnosti ,reakcionarno-nacionalističke grupe Pavelića koja je tijesno povezana s terorističkom organizacijom - Ustaša". Izrazom jačanja te političke opcije objašnjavan je i atentat na kralja Aleksandra u Marseilleu 9. listopada 1934. godine. Političke okolnosti nastale nakon smrti kralja Aleksandra i dolaska na vlast kabineta Milana Stojadinovića Sovjeti su vidjeli kao situaciju u kojoj je vanjskopolitička orijentacija nove vlade $\mathrm{k}$ jačanju odnosa s Njemačkom i Italijom dovela do „nezadovoljstva masa politikom vlade”, u vezi s čim je oživjela oporbena aktivnost i djelatnost različitih političkih stranaka i grupa, među kojima je jedno od centralnih mjesta zauzimala i hrvatska oporba. S obzirom na iznimno tijesnu pobjedu Stojadinovića nad oporbom, čiji je jedan od nosećih stupova bila hrvatska opozicijska grupacija na parlamentarnim izborima 1938., Sovjeti su procjenjivali da je hrvatska oporba dala ključni doprinos padu njegova kabineta. ${ }^{12}$

Sporazum od 26. kolovoza 1939. o stvaranju Banovine Hrvatske na sovjetskoj je strani tumačen rezultatom političke situacije u kojoj je uslijed pada Stojadinovića „srpska buržoazija bila prinuđena” tražiti kompromis s Hrvatima. Ulazak u vladu Dragiše Cvetkovića predstavnika Hrvatske seljačke stranke na čelu s njezinim vođom Vladkom Mačekom kao potpredsjednika i još petorice ministara oni su doživljavali kao posljedicu postignutoga sporazuma. Sam srpsko-hrvatski sporazum shvaćan je kao jamstvo „izvjesne hrvatske autonomije”, a činjenica da mu je ukazom namjesnika Pavla dan zakonski značaj vidom najviše zaštite odredaba sporazuma. Sa sovjetske točke gledišta, granice hrvatske banovine smatrane su širima nego što bi u nacionalnom smislu trebale biti. O samom karakteru autonomije govorili su kao o dosta širokim autonomnim vlastima na čijem se čelu nalazi ban kao kraljevski namjesnik, a da banovinske vlasti imaju nadležnost nad prosvjetom, poljoprivredom, industrijom i lokalnom samoupravom, ali da su ključne poluge vlasti koje su se ticale državnih pitanja, poput vanjske politike, obrane i unutarnje sigurnosti, ostale u nadležnosti središnjih vlasti. Za sovjetsku diplomaciju, koja je unutarnje jugoslavenske specifičnosti u uvjetima nedostatka valjanih informacija i atmosfere strogo nametnutih stega partijske birokracije u svojem centralnom aparatu tumačila polazeći s utvrđenih ideoloških točaka, stvaranje Banovine Hrvatske bio je „kompromis između hrvatske i srpske buržoazije” koji po prirodi stvari „nije mogao popraviti položaj radničkih masa Hrvatske", a pored toga bio je i izvor "novih prijatnih mjesta” u državnom aparatu za „vrh hrvatske buržoazije." ${ }^{13}$

Sovjetska diplomacija nije raspolagala preciznim informacijama o odnosu Hrvata prema politici približavanja Trećem Reichu u trenucima kada je pitanje jugoslavenskoga pristupanja Trojnom paktu došlo na razmatranje. Jedina

\footnotetext{
12 RF-AVPRF, 6, o.3, d. 373, p. 27, 1. 18.

13 RF-AVPRF, 6, o.3, d. 373, p. 27, 1. 19.
} 
pouzdana informacija koja im je bila poznata odnosila se na to da su petorica hrvatskih ministara podržala prijedlog za pristupanje Kraljevine Jugoslavije Trojnom paktu. Ostanak petorice hrvatskih ministara koji su glasali za takvu odluku i u novoformiranoj pučističkoj vladi pod predsjedništvom generala Dušana Simovića za sovjetsku je diplomaciju bio izraz ustupka sa srpske strane, koji je bio izazvan namjerom da se ne provociraju novi unutarnji sukobi i ne pogoršava unutarnja situacija u trenucima narastanja vanjske opasnosti. Sovjetsku stranu zabrinjavalo je to što hrvatska politička elita nije odmah prihvatila prijedlog da uđe u kabinet generala Simovića i da su pregovori potrajali punih osam dana, što je u uvjetima vanjskih prijetnji smatrano presedanom i znakom budućih problema i unutarnje nekompaktnosti države koja se suočava s mogućnošću vanjske agresije. Uslijed ograničene dostupnosti i sporoga protoka informacija Sovjeti su na osnovi podataka koji su se mogli dobiti analizom pisanja tiska zaključili da je prije definitivnoga pristanka na ulazak u Simovićevu vladu Maček postavio niz zahtjeva koji su se ticali ostanka na snazi odluke o jugoslavenskom pristupanju Trojnom paktu, očuvanja, a potom i širenja autonomnih prava Hrvatske zajamčenih sporazumom od 25. kolovoza 1939., kao i stvaranja Krunskoga savjeta, koji bi činili po jedan predstavnik srpskoga, hrvatskoga i slovenskoga naroda i koji bi mladom kralju, koji je u rujnu 1941. trebao postati punoljetan, bio glavni politički oslonac. Suzdržano držanje „Vodstva hrvatske buržoazije” prema prevratu koji se dogodio u noći 26./27. ožujka 1941. ocjenjivano je nastojanjem da se postojeća vanjskopolitička situacija iskoristi u cilju ne samo očuvanja postojećega položaja Hrvatske nego i dobivanja novih ustupaka. Vezano za političku budućnost Vladka Mačeka i Hrvatske seljačke stranke, sovjetska diplomatska služba procjenjivala je da Maček, ako bi krenuo linijom sukoba i ozbiljnijega razlaza s predstavnicima srpskih političkih partija, s točke gledišta Nijemaca, a posebno Talijana, ne bi predstavljao odgovarajuću političku figuru za ulogu „hrvatskoga Quislinga” jer bi Ante Pavelić, koji se u tom trenutku nalazio u Italiji i „koji je svojom profašističkom djelatnošću zaslužio puno povjerenje zemalja Osovine”, idealno koristio tom cilju. Sovjetski su analitičari Mačekovo ponašanje, kao i stavove vodećih ličnosti Hrvatske seljačke stranke, objašnjavali i potrebom da „slijede raspoloženje hrvatskih masa” jer je, prema sovjetskim ocjenama, „njihova negativna reakcija na pristupanje Jugoslavije paktu” jasno pokazala na čijoj se strani nalaze simpatije naroda. ${ }^{14}$ Među sovjetskim stručnjacima za Balkan smatralo se da je suštinski glavni razlog ulaska hrvatskih političara u Simovićevu vladu bio pokušaj da se izbjegne ratni sukob s Njemačkom. ${ }^{15}$ Utjecajem svih spomenutih faktora objašnjavalo se Mačekovo prihvaćanje sudjelovanja njegove političke stranke u novom kabinetu, za koji su Sovjeti tvrdili da je sastavljen na bazi "otpora kapitulantskim tendencijama”. ${ }^{16}$

14 RF-AVPRF, 6, o. 3, d. 373, p. 27, 1. 20.

15 RF-AVPRF, 6, o. 3, d. 373, p. 27, 1. 9.

16 RF-AVPRF, 6, o. 3, d. 373, p. 27, 1. 20. 
Za Sovjete je bilo sasvim jasno da se nova vlada neće pridržavati „kapitulantske politike Cvetkovićeve vlade" i da će Njemačka sa svoje strane uložiti velike napore da bi rasplamsala poznate srpsko-hrvatske razmirice. Sovjetske procjene govorile su da će Njemačka tijekom svojih nastojanja da oslabi Jugoslaviju iznutra sigurno zaigrati na postojeće srpsko-hrvatske suprotnosti, odnosno da će nastojati „posvađati Srbe i Hrvate” obećavajući Hrvatima izgradnju neovisne države po modelu Slovačke, a potom iskoristiti takvu državnu tvorevinu za daljnji nastup k ostatku jugoslavenskoga teritorija. Sovjete je na takvo rasuđivanje navodilo inzistiranje njemačkoga informacijskog ureda na obrazloženju da njemački tisak posvećuje posebnu pozornost hrvatskom pitanju zato što u Njemačkoj svaka forma „nacionalne stabilizacije na jugoistoku Europe izaziva puno suosjećanje”. Razmatrajući daljnje pravce njemačke politike u pogledu Jugoslavije, sovjetski vanjskopolitički analitičari zaključili su da je ulazak Mačeka i predstavnika Hrvatske seljačke stranke u vladu generala Simovića privremeno osujetio takav razvoj događaja, ali da će Njemačka, ako se odluči na vojnu akciju protiv Jugoslavije, zasigurno iskoristiti hrvatsko pitanje za unutarnje slabljenje jugoslavenske kraljevine. ${ }^{17}$ Primjećivali su da Njemačka sa svoje strane priprema razbijanje jugoslavenske države koristeći se propagandnom floskulom o „ugnjetenim Hrvatima” i „Srbima ugnjetačima”, što je imalo za cilj unošenje novoga vala razdora između dva najbrojnija jugoslavenska naroda, o čijem je međusobnom odnosu ovisio opstanak jugoslavenske države. ${ }^{18}$ Zato su $s$ velikom pažnjom pratili njemačke korake na tom planu. Analizirajući pisanje njemačkoga tiska, zaključili su da on postojano inzistira na tome da su Hrvati, za razliku od Srba, „prijateljski nastrojeni” prema Njemačkoj i da kao potvrdu takva stava iznosi činjenice da su se tijekom „prethodnoga svjetskog rata Hrvati borili zajedno s Nijemcima”, istovremeno izražavajući uvjerenje da Hrvati „neće izdati svoga starog saveznika”. S tim u vezi primijećeno je da su se neposredno po izvedenom vojnom puču na stranicama njemačkoga tiska pojavile prve naznake mogućnosti stvaranja „nezavisne hrvatske države”. Zaključivali su da je takav oblik njemačke propagande, čiji je cilj nesumnjivo bio odvajanje Hrvata od Srba, dobio posebno široke razmjere s početkom njemačkih vojnih djelovanja protiv Jugoslavije. Registrirano je da su njemačke radijske stanice već prvoga dana rata, 6. travnja, na hrvatskom jeziku prenosile obraćanje kojim su Hrvati pozivani da stvore „slobodnu hrvatsku državu uz pomoć njemačke vojske koja će dati Hrvatima slobodu”. ${ }^{19}$ Već 7. travnja sovjetska diplomacija uočila je da je njemački informacijski ured prenio poziv Ante Pavelića u kojem se govorilo da će Hrvati biti na strani država Osovine prilikom uspostavljanja novoga poretka u Europi. Zapaženo je i drugo priopćenje njemačkih radijskih stanica, u kojem se naglašavalo da se Vladka Mačeka više ne smatra vođom hrvatskoga naroda i da kao takav više nema pravo istupati u njegovo ime. ${ }^{20}$

\footnotetext{
17 RF-AVPRF, 6, o. 3, d. 373, p. 27, 1. 13.

18 RF-AVPRF, 6, o. 3, d. 373, p. 27, 1. 43.

19 RF-AVPRF, 6, o. 3, d. 373, p. 27, 1. 21.

20 Isto.
} 
Sovjetske diplomatske strukture budno su pratile i odnos Italije prema zbivanjima u Hrvatskoj. Raspolagali su informacijama da je talijanska agencija Stefani 7. travnja prenijela tekst obraćanja Ante Pavelića Benitu Mussoliniju, u kojem ga je Pavelić oslovljavao kao „velikoga prijatelja malih naroda” i izražavao mu zahvalnost „za oslobođenje koje će on donijeti hrvatskom narodu”. Na temelju toga sovjetska je diplomacija izvela zaključak o krajnjim ciljevima njemačke i talijanske politike u pogledu hrvatskoga pitanja. Sovjeti su bili čvrsto uvjereni da će u slučaju njemačke okupacije Hrvatske jedan od prvih njemačkih koraka biti vezan za proglašenje nezavisne Hrvatske i organizaciju vlasti „kvislinškoga tipa”. Smatrali su da se to i dogodilo 10. travnja jer se na čelu vlasti novoproglašene države našao Ante Pavelić. Za njih je poseban paradoks bilo proglašenje „slobodne države” čiji je prvi potez bio poziv njemačkoj vojsci da uđe na njezin teritorij. Takav poziv upućen vojsci „zemlje pokrovitelja” na sovjetskoj je strani smatran izravnim izrazom negacije bilo kakve ideje o slobodnoj i nezavisnoj državi. ${ }^{21}$ Antu Pavelića sovjetska je diplomacija smatrala „agentom država Osovine”. Jedan od dokaza koji su koristili radi potkrepljivanja te tvrdnje bila je okolnost da su samo nekoliko dana po njezinu proglašenju Nezavisnu Državu Hrvatsku priznale Njemačka, Italija i Mađarska. ${ }^{22}$

Analizirajući tijek i ishod borbenih djelovanja na prostoru Hrvatske u kratkotrajnom Travanjskom ratu, sovjetski vojni izaslanik u Kraljevini Jugoslaviji general-major Aleksandar Samohin smatrao je da je sudbina jugoslavenske sjeverne fronte bila odlučena u večernjim satima 9. travnja nakon radijskoga obraćanja Ante Pavelića hrvatskom narodu. Svjedočio je da su hrvatski oficiri i vojnici nakon toga - a on je procjenjivao da su u tim trenucima oni činili između 35 i 40 posto ukupnoga ljudstva jugoslavenskih oružanih snaga - počeli masovno napuštati redove jugoslavenske vojske odbivši se dalje boriti protiv Njemačke i Italije. Nakon toga je, po Samohinovim procjenama, Nijemcima bio otvoren put k Zagrebu, a jugoslavenska vojska bila je prisiljena započeti s povlačenjem na svim ostalim sektorima sjeverne fronte. ${ }^{23}$ Po njemu, drugi demoralizirajući utjecaj na hrvatske oficire i vojnike imale su vijesti da je Vladko Maček napustio jugoslavensku vladu i krenuo natrag u Hrvatsku. Smatrao je da je na taj način Maček poslao poruku Hrvatima da napuste redove jugoslavenske vojske i otkažu poslušnost jugoslavenskoj državi. ${ }^{24}$ Inače, general Samohin, koji je tijekom povlačenja preko Bosne i Hercegovine pratio jugoslavensku vladu zajedno sa sovjetskim otpravnikom poslova Viktorom Lebedevim, bio je u prilici suočiti se na licu mjesta s razmjerima jugoslavenskoga vojnog poraza, raspadom države i formiranjem civilnih i vojnih organa vlasti Nezavisne Države Hrvatske na samom terenu. Prateći jugoslavensku vladu automobilima, uslijed zakrčenosti loših putova na prostoru Bosne i Hercegovine automobili sovjetskoga poslanstva zastali su na putu k Mostaru

${ }^{21}$ RF-AVPRF, 6, o. 3, d. 373, p. 27, 1. 43.

${ }^{22}$ RF-AVPRF, 6, o. 3, d. 373, p. 27, 1. 28.

${ }^{23}$ RF-AVPRF, 6, o. 3, d. 371, p. 27, 1. 45.

${ }^{24}$ RF-AVPRF, 6, o. 3, d. 373, p. 27, 1. 46. 
kod sela Slatine radi odmora u noći 13./14. travnja 1941. godine. Probudili su ih naoružani ljudi u polucivilnoj i poluvojnoj odjeći s uperenim puškama. Veoma su teško komunicirali, ali su uspjeli objasniti da su sovjetski diplomati i da njihovi sugovornici trebaju skloniti puške. Nakon toga su shvatili da su suočeni s odredom ustaša. ${ }^{25}$ Zapovjednik toga ustaškog odreda objasnio im je da se nalaze u „pograničnoj zoni” i da se moraju momentalno uputiti prema najbližem gradu. Zadržao je njihove dokumente držeći im kraće predavanje o uspjesima "hrvatskoga oružja”. Dalje su se kretali pod oružanom pratnjom ustaške jedinice. Dopratili su ih do Prozora, gdje ih je okružen vodom naoružanih ljudi sačekao lokalni ustaški zapovjednik, za koga su poslije Lebedev i Samohin tvrdili da je izgledao poput „operetskoga švercera”. Prema njima se ponašao veoma ljubazno, nudeći svoju pomoć. Priopćio im je da se nalaze u „pograničnoj zoni” i da ne mogu ostati jer su tu moguća ratna djelovanja. Sovjetskim diplomatima bilo je jasno da ih neće pustiti da odu s prostora novoproglašene hrvatske države i da će im biti vrlo teško vratiti se u Beograd preko Zagreba. Svjedočili su da je na ulicama Prozora bilo mnogo svijeta i da su oduševljeno pozdravljali novu vlast. ${ }^{26} \mathrm{U}$ Bugojnom su se u zgradi gradskoga poglavarstva sreli $s$,nizom ustaških funkcionara zrele životne dobi” koji su oduševljeno govorili o uspjesima Ustaškoga pokreta, otvoreno rekavši da će sa sovjetskim diplomatima postupati onako kako im bude bilo naređeno. ${ }^{27}$ Dalje su se preko Livna, Sinja, Knina, Benkovca, Bihaća i Karlovca konačno obreli u Zagrebu. ${ }^{28}$ Kako su se u Zagrebu zadržali kratko, čekajući dozvolu njemačkih vlasti za povratak u Beograd, i sve vrijeme bili pod njemačkom kontrolom, nisu se mogli upoznati s karakterom novouspostavljenoga režima u njegovoj prijestolnici. Pod njemačkom su se pratnjom od Zagreba do Beograda kretali putovima druge i treće vrste, a ne glavnim magistralnim putovima. Krećući se pravcima kojima su njemačke jedinice prošle samo nekoliko dana prije, sovjetski diplomati uvjerili su se da su u „svim naseljima u izobilju izvješene njemačke i hrvatske zastave”, kao i da djeca „bukvalno svuda podižu ruku u znak pozdrava i bacaju cvijeće". S takvim su se slikama susretali u Dugom Selu, Kutini, Novskoj, Novoj Gradiški i Slavonskom Brodu. ${ }^{29}$

Sovjeti nisu imali dileme da je cilj njemačke politike na prostoru Hrvatske stvaranje marionetske države koja podsjeća na Slovačku i nalazi se pod punim njemačkim protektoratom. Vezano za budući razvoj događaja na hrvatskom tlu, neposredno po proglašenju Nezavisne Države Hrvatske sovjetska je diplomacija već 11 . travnja 1941. zaključila da će se ona naći u poziciji ,jabuke razdora” između Italije i Njemačke u onom trenutku kada „Mussolini ne bude u tako zavisnom položaju u odnosu na svoga njemačkog saveznika" jer su njemačke i talijanske interese na njezinim prostorima smatrali duboko

\footnotetext{
25 RF-AVPRF, 6, o. 3, d. 373, p. 27, 1. 102.

26 RF-AVPRF, 6, o. 3, d. 373, p. 27, 1. 103.

27 RF-AVPRF, 6, o. 3, d. 373, p. 27, 1. 104.

28 RF-AVPRF, 6, o. 3, d. 373, p. 27, 1. 108.

29 RF-AVPRF, 6, o. 3, d. 373, p. 27, 1. 109.
} 
suprotstavljenim. ${ }^{30}$ Svoje su procjene pravdali uvjerenjem da je „talijanski fašizam" oduvijek isticao težnju da ovlada objema obalama Jadranskoga mora i da je zauzimanje Albanije bio prvi praktični korak na putu ostvarenja toga cilja. Za njih je uspostava Nezavisne Države Hrvatske pod zaštitom njemačke vojske, koja je prethodno zauzela Zagreb, značila da će Mussolini silom prilika biti prinuđen „oprostiti se od takvih maštanja” i morati gledati „Nijemce kao gospodare Jadranskoga mora”, do kojega će oni stići preko hrvatskoga teritorija. ${ }^{31} \mathrm{~S}$ tim u vezi primijećeno je da talijanski tisak u prvim danima po proglašenju Nezavisne Države Hrvatske nije govorio o potrebi pripojenja Italiji Slovenije i Hrvatske nego samo Dalmacije, što se na sovjetskoj strani držalo izrazom realnoga stanja na terenu, odnosno talijanskom nemoći da u novonastalim okolnostima artikulira svoje prijašnje ideje o pripojenju Slovenije i Dalmacije, kao i uspostavljanju talijanskoga protektorata nad Hrvatskom. Zato se čvrsto vjerovalo da će usprkos talijanskim težnjama Hrvatska u najbližoj budućnosti biti njemački protektorat po ugledu na Slovačku, a da će eventualno dio Dalmacije biti zona talijanskoga interesa, što bi trebalo biti riješeno na posebnoj konferenciji, za koju je sovjetska diplomacija 19. travnja 1941. pretpostavljala da će u najkraćem roku biti održana u Beču. ${ }^{32}$

Za sovjetsku je stranu proglašenje Nezavisne Države Hrvatske pod zaštitom Njemačke i Italije bilo obrazac buduće podjele jugoslavenskoga teritorija. U pogledu suprotstavljenosti njemačkih i talijanskih interesa na prostoru Hrvatske sovjetska diplomacija imala je saznanja da je već tijekom susreta talijanskoga ministra vanjskih poslova grofa Ciana s njegovim njemačkim kolegom Ribbentropom u Beču od 20. do 22. travnja bilo ozbiljnijih razmimoilaženja zbog njemačkoga nezadovoljstva talijanskim pretenzijama na prostoru Nezavisne Države Hrvatske jer je Italija otvoreno zahtijevala da joj se preda protektorat nad Hrvatskom, kao i cjelokupni teritorij Dalmacije. ${ }^{33} \mathrm{Na}$ sovjetskoj se strani procjenjivalo da će to pitanje biti jedan od gorućih problema jer se Njemačka neće složiti s talijanskim pretenzijama, odnosno neće izaći ususret talijanskim zahtjevima za aneksiju čitave dalmatinske obale i na taj način lišiti Nezavisnu Državu Hrvatsku, pa neizravno i sebe, izlaska na Jadransko more. Kako nisu imali na raspolaganju potpune informacije o ishodu susreta Ciana i Ribbentropa, Sovjeti su na osnovi posrednih informacija zaključili da su razgovori završili postizanjem kompromisa kojim je Italija odustala od mnogih svojih pretenzija. Procjenjivalo se da Italija neće lako odustati od svojih namjera. Takvu sovjetskom rezoniranju na ruku je išla i činjenica da je nova hrvatska vlast na čelu s Pavelićem bila usko povezana s Italijom i da joj je mnogo dugovala za dugogodišnju potporu i utočište koje im je pružala u predratnom periodu. Izraz pojačane talijanske aktivnosti koja bi imala za cilj jačanje talijanskoga utjecaja u

\footnotetext{
${ }^{30}$ O suprotstavljenosti njemačkih i talijanskih interesa na prostoru Hrvatske opširnije: KRIZMAN, NDH između Hitlera i Mussolinija.

31 RF-AVPRF, 6, o. 3, d. 373, p. 27, 1. 21.

32 RF-AVPRF, 6, o. 3, d. 373, p. 27, 1. 29-30.

33 RF-AVPRF, 6, o. 3, d. 373, p. 27, 1. 36.
} 
Nezavisnoj Državi Hrvatskoj Sovjeti su vidjeli u zakonu objavljenom 15. svibnja 1941., kojim je hrvatska država proglašena monarhijom, i odlasku hrvatske državne delegacije na čelu s Antom Pavelićem u Rim već 18. svibnja da ponude hrvatsku krunu kraljevskom domu Savojskih. Do njih su dolazile i informacije da je za hrvatskoga kralja izabran vojvoda od Spoleta i da se priprema njegovo službeno krunjenje u Banjoj Luci. Kao poseban dokaz Pavelićeva vezivanja za Italiju navodio se niz novih zakona koje je potpisao sam Pavelić, koji su po sovjetskim shvaćanjima i viđenjima Nezavisnu Državu Hrvatsku dovodili u apsolutno vazalni položaj u odnosu na Italiju. ${ }^{34}$

Postignute sporazume između Italije i Nezavisne Države Hrvatske Sovjeti su vidjeli kao novi val talijanske infiltracije na Balkanu. Smatrali su da je Nezavisna Država Hrvatska sporazumom o razgraničenju s Italijom - kojim je Italiji predan Sušak s okolicom, dio Dalmacije s lukama Zadrom, Šibenikom i Splitom uz gotovo sve nekadašnje jugoslavenske otoke na Jadranu i dio obale između Dubrovnika i Kotora - suštinski potvrdila svoju ovisnost o Italiji. Na isti način tumačen je i sporazum kojim se hrvatska strana obvezala demilitarizirati obalu Jadranskoga mora koja je ostala u sastavu Nezavisne Države Hrvatske, odrekla prava na posjedovanje ratne mornarice i dopustila Italiji pravo na slobodan transport ratnoga materijala preko hrvatskoga teritorija. Sovjetska je diplomacija vjerovala da je Italija svoj dominantan položaj u odnosu na novoproglašenu hrvatsku državu definirala sporazumom o jamstvima i suradnji, kojim je Italija jamčila teritorijalnu cjelovitost Hrvatskoj, a ova se zauzvrat obvezala da neće zaključivati nikakve sporazume koji bi bili proturječni sporazumu sklopljenom s Italijom. Hrvatska se time obvezala i na suradnju s Italijom u procesu izgradnje vlastitih oružanih snaga, kao i na zaključenje carinskih, međuvalutnih i željezničkih ugovora, čime je, po sovjetskim ocjenama, svoju sudbinu potpuno vezala za nju u razdoblju od 25 godina, koliko je trebao vrijediti zaključeni sporazum. ${ }^{35} \mathrm{U}$ svemu tome Sovjeti su vidjeli zaokruživanje procesa pretvaranja Nezavisne Države Hrvatske u potpuni talijanski protektorat. Na sovjetskoj se strani smatralo da je Njemačka učinila određene ustupke Italiji u odnosu na hrvatsko pitanje bez osiguravanja odgovarajuće kompenzacije na drugoj strani. U takvim političkim potezima državnoga vodstva Nezavisne Države Hrvatske sovjetska je strana vidjela još jedan dokaz da su „rukovodioci Hrvatske u osobi Pavelića, Kvaternika i njihovih suradnika” ništa drugo doli predstavnici „vjerne agenture talijanskoga fašizma”. ${ }^{6}$

U pogledu novouspostavljenoga režima na prostoru Hrvatske Sovjeti su smatrali da se on samo u formalnom smislu formirao na temelju „ustaškoga prevrata” te da se suštinski nikako ne radi o „vlasti slobodne države”, kako se to često isticalo u jeziku ustaške propagande, nego da u Hrvatskoj stvarno vlada „njemački bajunet”. Primjećivali su i da se metode njemačkih vojnih vlasti na

34 RF-AVPRF, 6, o. 3, d. 373, p. 27, 1. 37.

35 RF-AVPRF, 6, o. 3, d. 373, p. 27, 1. 38.

36 RF-AVPRF, 6, o. 3, d. 373, p. 27, 1. 39. 
prostoru Hrvatske razlikuju od onih kojima se koriste na tlu okupirane Srbije. O samom državnom aparatu Nezavisne Države Hrvatske govorili su kao o državnoj strukturi na čijem se čelu nalazi Ante Pavelić kao vođa nacionalističke organizacije koja je, po sovjetskim shvaćanjima, „prvo hranjena od strane Talijana, a zatim Nijemaca". Sovjetske diplomatske strukture malo su znale o njegovim prvim političkim potezima jer na teritoriju Nezavisne Države Hrvatske nisu imale svoja službena predstavništva, a poslanstvo u Beogradu bilo je, po nalogu njemačkih okupacijskih vlasti, u svojevrsnoj izolaciji i pripremi za evakuaciju, pa je dotok valjanih informacija bio iznimno ograničen i kontroliran. Znalo se da Pavelić nastoji na temelju razvalina staroga državnog poretka ustanoviti nove državne institucije. U prvom je redu primijećeno da inzistira na završetku organizacije oružanih snaga, čiji su temelj činili hrvatski dijelovi nekadašnje jugoslavenske vojske koji su tijekom Travanjskoga rata odbili izvršavati naredbe jugoslavenskoga vojnog vrha. ${ }^{37}$ Sovjetske informacije govorile su i da će ekonomski sustav novoproglašene države biti usklađen s ekonomijama država koje pripadaju Osovini. Među njima je vladalo uvjerenje da će po ugledu na Njemačku „radikalno biti riješena židovska i masonska pitanja”, da će „političke stranke biti raspuštene i nadalje ostati zabranjene”, a da će nosilac političke vlasti u zemlji biti isključivo Ustaški pokret. ${ }^{38} \mathrm{Na}$ sovjetskoj strani živo se pratilo i nastojanje novih hrvatskih vlasti da u zemlju vrate desetak tisuća emigranata. Za njih je i vanjskopolitička orijentacija režima Nezavisne Države Hrvatske bila sasvim izvjesna. Nisu imali dileme da će se vanjska politika Pavelićeva režima kretati isključivo u okvirima vanjske politike i interesa zemalja Osovine. $\mathrm{Na}$ takav ih je zaključak, pored analize međunarodnih okolnosti i politike Njemačke i Italije na tom planu, navodila i propaganda Pavelićevih organa vlasti, koja je nedvosmisleno isticala da hrvatski narod „nikad neće zaboraviti tko mu je donio slobodu i na čijoj je strani naše mjesto u međunarodnim odnosima”. U sovjetskoj je vizuri i sama činjenica da su Mađarska, Njemačka i Italija požurile s priznanjem proglašene hrvatske države, a potom u vrlo kratkom roku uputile i službene diplomatske predstavnike u njezinu prijestolnicu, bila dokaz međunarodnoga statusa Nezavisne Države Hrvatske. ${ }^{39}$

Negativan stav sovjetske vlade i diplomacije prema nastanku Nezavisne Države Hrvatske nije bio poznat jugoslavenskoj vladi u izbjeglištvu. Zato je sovjetski privremeni prekid diplomatskih odnosa s Kraljevinom Jugoslavijom, do kojega je došlo 8. svibnja 1941. uslijed teških njemačkih diplomatskih pritisaka, izazvao sumnju na jugoslavenskoj strani da se radi o pripremnom aktu koji znači uvod u sovjetsko priznanje Nezavisne Države Hrvatske i potom uspostavu redovnih diplomatskih odnosa. Jugoslavenski strah bio je pojačan vijestima koje su dopirale do diplomatske službe jugoslavenske vlade u izbjeglištvu da se Rumunjska priprema u sljedećim danima priznati Nezavisnu Državu Hrvat-

\footnotetext{
${ }^{37}$ O stvaranju oružanih snaga Nezavisne Države Hrvatske opširnije: BARIĆ, Ustroj kopnene vojske domobranstva Nezavisne Države Hrvatske; OBHOĐAŠ et al., Ustaška vojnica.

38 RF-AVPRF, 6, o. 3, d. 373, p. 27, 1. 45.

39 RF-AVPRF, 6, o. 3, d. 373, p. 27, 1. 46.
} 
sku. ${ }^{40}$ Kada je zamjenik sovjetskoga narodnog komesara za vanjske poslove Vjačeslava Molotova Andrej Višinski priopćio odluku svoje vlade da prekine odnose s vladom jugoslavenske kraljevine njezinu poslaniku u Moskvi Milanu Gavriloviću, kao razloge je iznio nepostojanje komunikacije s predstavnicima jugoslavenske vlade u Palestini, a Gavrilović ga je otvoreno pitao radi li se o pripremama za sovjetsko priznanje Nezavisne Države Hrvatske. ${ }^{41}$ Višinski mu je u skladu sa svojim stilom komunikacije kratko i dosta zagonetno odgovorio da se za sada to pitanje ne postavlja. ${ }^{42}$ Neodređeni sovjetski odgovor izazivao je strahove i sumnje da bi u bliskoj budućnosti, posebno uslijed njemačkoga pritiska na Sovjetski Savez i sovjetskoga nastojanja da izbjegnu daljnju konfrontaciju s Trećim Reichom, moglo doći do službenoga priznanja proglašene hrvatske države. Sumnje su potrajale sve do početka njemačkoga napada na Sovjetski Savez 22. lipnja 1941. godine. U trenutku kada se Sovjetski Savez našao u sukobu sa zemljama Osovine postalo je sasvim jasno da se sovjetska vlada i diplomacija neće odlučiti na takav korak. Sumnje u moguće sovjetske namjere toga tipa potpuno su otpuhane izjavom sovjetskoga komesara za vanjske poslove Vjačeslava Molotova danom neposredno po otpočinjanju ratnoga sukoba na sovjetskim granicama, u kojoj je nabrajajući dotadašnje žrtve fašističke agresije apostrofirao srpski narod bez spomena bilo kojega drugoga jugoslavenskog naroda, čime je jasno poručio da Nezavisnu Državu Hrvatsku smatra neprijateljskom državnom tvorevinom. ${ }^{43}$ Kako se radilo o prvoj sovjetskoj javnoj osudi njemačkoga napada na Jugoslaviju, njome su trasirani pravci budućega odnosa prema jugoslavenskoj vladi u izbjeglištvu i zbivanjima na prostoru okupiranoga jugoslavenskog teritorija.

Sovjetska diplomacija promatrala je hrvatsko pitanje u jugoslavenskoj kraljevini kroz prizmu vladajuće ideologije, u početku ne priznajući jugoslavensku državu, a potom zalažući se za njezino prestrukturiranje na federativnoj osnovi. Postojeće srpsko-hrvatske nesuglasice i razmirice vidjela je kao izraz prerastanja međuklasnih u međunacionalne sukobe. Početak Drugoga svjetskog rata i približavanje sukoba jugoslavenskim granicama prisilili su sovjetsku stranu da unutarnje jugoslavenske probleme, pa tako i hrvatsko pitanje, promatra u kontekstu ne samo unutarnjih političkih i međunacionalnih odnosa nego i u ravni prelamanja interesa zainteresiranih sila. Procjenjivali su da će Njemačka u sklopu politike širenja svojega utjecaja na Balkanu nastojati iskoristiti hrvatsko pitanje za unutarnju destabilizaciju Kraljevine Jugoslavije. U tom je smislu sovjetska diplomacija bila uvjerena da će Njemačka iskoristiti prostor Hrvatske kao točku oslonca za svoje daljnje nastupanje na jugoslavenskom prostoru. Procjena da će Njemačka i Italija umjesto Hrvatske seljačke

${ }^{40}$ O političkim okolnostima u kojima je došlo do prekida jugoslavensko-sovjetskih diplomatskih odnosa 8. svibnja 1941. opširnije: ЖИВОТИЋ, Југословенско-совјетски односи 19391941, 413-416.

41 Документы внешней политики, t. 23, k. 2-2, 661-662.

${ }^{42}$ RF-AVPRF, 6, o. 3, d. 27, p. 3, 1. 1-4.

${ }^{43}$ Односи Југоставије и Русије (СССР) 1941-1945, 60-61. 
stranke nastojati svoj utjecaj u Hrvatskoj ostvariti preko Ustaškoga pokreta kao ideološki bližega i pouzdanijega saveznika pokazala se točnom. Isto tako sovjetska strana smatrala je novoproglašenu Nezavisnu Državu Hrvatsku kvislinškom tvorevinom na čijem se teritoriju križaju interesi Njemačke i Italije, pri čemu je uz njemačko dopuštenje ona pretvorena u talijanski protektorat. Zato ju nisu smatrali slobodnom, a samim tim ni političkom tvorevinom koja zaslužuje međunarodnopravni subjektivitet.

\section{Neobjavljeni arhivski izvori}

RF-AVPRF: Ruska Federacija, Архив внешней политики Российской Федерации, fond 6, Секретариат Молотова.

RF-RGASPI: Ruska Federacija, Российский государственный архив социально-политической истории, fond 17, Политбюро Централного комитета СКП (б).

\section{Objavljeni arhivski izvori}

Документы внешней политики, т. 23, к. 2-2. Москва: МИД РФ, 1998.

Односи Југоставије и Русије (СССР) 1941-1945. Документи и материјали. Београд: Војноисторијски институт, 1996.

\section{Literatura}

BARIĆ, Nikica. Ustroj kopnene vojske domobranstva Nezavisne Države Hrvatske. Zagreb: Hrvatski institut za povijest, 2003.

BERGVIN, H. Džejms. Imperija na Jadranu. Musolinijevo osvajanje Jugoslavije 1941-1943. Beograd: Službeni glasnik, 2007.

БЈЕЛАЈАЦ, Миле. „Покушај стратешког ослонца на СССР 1939-1941”. Војноисторијски гласник (2006), br. 1-2: 41-66.

BOBAN, Ljubo. Maček i politika Hrvatske seljačke stranke 1928-1941. Iz povijesti hrvatskog pitanja, II. Zagreb: Liber, 1974.

CVETKOVIĆ, Slavoljub. „Jugoslovensko-sovjetski pregovori 1941. o zaključenju ugovora o prijateljstvu i nenapadanju”. Vojnoistorijski glasnik (1991), br. 1: 11-26.

JAREB, Mario. Ustaško-domobranski pokret od nastanka do travnja 1941. Zagreb: Hrvatski institut za povijest; Školska knjiga, 2006.

ЈОВАНОВИЋ, Драгољуб. Политичке успомене, 6. Београд: Службени лист СРЈ, 1997.

KRIZMAN, Bogdan. NDH izmedu Hitlera i Mussolinija. Zagreb: Globus, 1987. 
MAČEK, Vladko. Memoari. Zagreb: Hrvatska seljačka stranka, 1992.

NENEZIĆ, Dragan. Jugoslovenske oblasti pod Italijom 1941-1943. Beograd: Vojnoistorijski institut, 1999.

OBHOĐAŠ, Amir; WERHAS, Mario; DIMITRIJEVIĆ, Bojan; DESPOT, Zvonimir. Ustaška vojnica. Oružana sila Ustaškog pokreta u Nezavisnoj Državi Hrvatskoj 1941-1945. Zagreb: Despot Infinitus, 2013.

ВОЛКОВ, Владимир; ГИБИАНСКИЙ, Леонид. Восточная Европа между Гитлером и Сталиным 1939-1941. Москва: Индрик, 1999.

ЖИВОТИЋ, Александар. Југословенско-совјетски односи 1939-1941. Београд: Филип Вишњић, 2016. 


\section{SUMMARY}

\section{Soviet Diplomacy on the Creation of the Independent State of Croatia}

During the interwar period, in the climate of a lack of regular diplomatic relations between the Yugoslav kingdom and Soviet Russia/the USSR, the Soviet side came to see the Yugoslav state as an artificial creation that needed to be destroyed. Later, the stance that the Yugoslav state needed to be reconstituted on a federal basis became more accepted. Despite a series of attempts to normalise interstate relations, a series of controversies, one of the most important being the Soviet stance towards the national question in Yugoslavia, resulted in a lack of regular diplomatic communication between the two states. After long negotiations, official diplomatic relations were established in summer 1940. The most influential Croatian political party - the Croatian Peasant Party led by Vladko Maček - supported the Yugoslav rapprochement with the USSR, seeing in it a sort of counterbalance to aggressive Italian policy towards the Balkans. The Soviet side saw Croatian-Serbian relations - the backbone of the Yugoslav state - as deeply conflicting interests of two opposed bourgeoisies that maintain their political monopoly through compromises and agreements and thus oppose the revolutionary strivings of the working people. They believed that Italy, and especially Germany, would try to use the deep-rooted contradictions between the Serbian and Croatian national bodies in the Yugoslav state in order to destabilise it from within. Soviet diplomacy was convinced that Germany would try to convert Croatia into a starting point for spreading its influence in the Yugoslav lands. They anticipated that, instead of the Croatian Peasant Party, the Axis forces would place their trust in the Ustasha movement and entrust its leader, Ante Pavelić, to lead an independent Croatian state, which would in fact be a puppet state similar to Slovakia. They believed that the Ustasha movement, through its statements and proclamations during the April War, managed to play an important role in the collapse of the Yugoslav kingdom. The Soviets considered the newly-established Croatian state under German and Italian patronage a quisling political creation completely dependent on the Axis powers. The Independent State of Croatia's political and economic treaties with Italy were interpreted as proof of its status as an Italian protectorate. Despite the fears of the Yugoslav government in exile that the USSR could recognise the Independent State of Croatia and establish diplomatic relations with it, this did not come to pass due to the Soviets' negation of its state subjectivity.

Key words: Soviet Union; Independent State of Croatia; diplomacy; Germany; Italy; 1941; April War (Axis invasion of Yugoslavia). 